\title{
Focalization and Word Order in Old Italo-Romance
}

\author{
Silvio Cruschina
}

University of Manchester. School of Languages, Linguistics and Cultures

silvio.cruschina@manchester.ac.uk

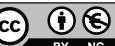

Received: December 202010

Accepted: April 152011

\begin{abstract}
This paper sets out a comparison between modern and old Italo-Romance varieties with the aim of understanding the mechanisms that characterize the syntactic operations associated with the information structure of the sentence, as well as identifying their triggering factors. In particular, this study concentrates on the process of focalization and the movement operations related to it: constituent fronting and verb movement. In light of the synchronic variation found in modern Italo-Romance varieties, it is argued that most of the properties generally attributed to a V2 system found in the languages in question are instead associated with discourse-related features and functional projections. A distinction between a higher, left peripheral FocP and a lower, clause-internal FocP provides the basis for an account of both synchronic and diachronic variation, the analysis of which rests on a correlation between word order changes in diachrony, discourse-related features, and functional projections.
\end{abstract}

Keywords: Medieval Italo-Romance; Sicilian; Sardinian; synchronic variation; diachronic change; word order; focalization; contrastive focus; informational focus; functional projections.

\section{Table of Contents}

1. Introduction

2. Focalization and variation in modern Italo-Romance

3. The properties of Focalization in Old Italo-Romance

4. Old Sicilian and Old Sardinian
5. Criterial analysis of Focalization: discourse-related features and functional projections

6. Conclusions and some final speculations

Texts and Sources

References

\section{Introduction}

Medieval Romance varieties are claimed to have been characterized by a V2 word order featuring the fronting of one or more constituents to the left of the inflected verb (cf. Benincà 1983/84, 1995, 2006, Adams 1987, Fontana 1993, 1997, Roberts 1993, Ribeiro 1995, Torres Morais 1995, Vance 1997, Salvi 2000, 2001, 2004, 2011, Ledgeway 2007, 2008, 2011, among many others). It is generally acknowl- 
edged in the literature that, from a pragmatic and semantic viewpoint, the fronted elements correspond to discourse-related notions, such as those of topic and focus. The precise nature of the fronted constituents, however, is not always unambiguous and may sometimes remain open to two or more interpretations. The lack of prosodic clues, coupled with significant syntactic differences between Medieval and Modern Romance varieties, especially with regard to topicalization and clitic resumption, make it difficult in certain cases to establish whether a given fronted constituent is a topic or a focus (Vanelli 1986, 1999). More controversial is the motivation for the movement of the verb. The primary aim of this paper is to provide a means of distinguishing between fronting configurations in Old ItaloRomance, and in particular between fronting of topics and fronting of foci, which, due to the absence of clitic resumption, are often superficially identical. Following a methodology started in Cruschina and Sitaridou (2010), we will analyse the data from Medieval Romance through a comparison with some Modern Romance varieties. In this study we will place particular emphasis on the process of focalization in Italo-Romance, and will use synchronic variation to search for diachronic evidence. The examination of modern data from some Italo-Romance varieties, such as Sardinian and Sicilian, where unlike the majority of the Romance languages focalization is not limited to a contrastive interpretation, will help us to understand the properties of focalization in the Medieval varieties, as well as some fundamental diachronic issues concerning word order change and its relationship with information structure. ${ }^{1}$ Drawing on recent claims, in particular Fischer (2010), we follow the hypothesis that the reanalysis of functional projections can be triggered by word order changes. In particular, the association of focalization with a specific focus projection may lead, through a change registered in the featural make-up of the functional head, to the deactivation of a projection and to the activation of another.

The paper is organized as follows. In the next section we will go through some preliminary distinctions which are essential in understanding the synchronic variation with respect to focalization in Modern Italo-Romance. Focalization will be briefly compared to topicalization and a distinction will be drawn between two types of focus with distinct syntactic correlates, i.e. contrastive focus and informational (non contrastive) focus. Section 3 will be devoted to Old Italo-Romance, and specifically to the properties of the fronted constituents and the analogies between Modern and Old Italo-Romance. The appropriateness of the V2 label generally used in reference to the syntax of these varieties will be discussed. It will emerge that of the modern varieties, Sardinian and Sicilian still show some similarities with the medieval syntax, particularly with respect to Focus Fronting (henceforth FF). In section 4 we will attempt to offer an answer to the question of whether these syntactic properties of Sicilian and Sardinian have been preserved since medieval times or have developed, independently, at a later stage. Adopting a criterial

1. For its distinctive properties, many scholars do not consider Sardinian as part of the Italo-Romance group. However, for sake of simplicity here we include this language in the Italo-Romance family without taking any particular stand on this matter. Another classificatory or labelling clarification concerns Old Italian, by which we simply mean Medieval Florentine. 
analysis to focalization (cf. §5), section 6 presents a defence of the hypothesis that a correlation exists between word order changes, information-structure features, and functional projections.

\section{Focalization and variation in modern Italo-Romance}

Modern Italo-Romance varieties present a variegated picture with respect to focalization (cf. Cruschina 2008). Some varieties never mark focalization by movement to the left periphery of the sentence. This is the case in Turinese, where the focus constituent occurs in a postverbal position, regardless of its interpretation (Paoli 2003). In contrast, Standard Italian and many other Italo-Romance varieties allow the fronting of the focus constituent only in the context of a contrastive interpretation (cf. Benincà 1988, Rizzi 1997, among others). In Sicilian (Cruschina 2006, 2008, 2010a, Bentley 2007) and in Sardinian (Jones 1993, Mensching and Remberger 2010), on the other hand, the focus constituent tends to be fronted irrespective of its interpretation, regularly appearing at the beginning of the sentence. This synchronic variation can be accounted for by adopting the recent cartographic claims concerning the structure of the 'left peripheries' within the sentence, that is the discourse-related functional projections to the left of the core functional nodes $\mathrm{C}$ and v. According to these claims, two focus projections are present within the sentence: one in the left periphery of the sentence (cf. Rizzi 1997), the other in the left periphery of the vP (cf. Belletti 1999, 2001, 2004). As will be discussed below, languages differ in the activation of either projection as the designated position where focalization is syntactically marked.

Despite this variation with respect to the position of the focus, in Modern Italian, as well as in most modern Italo-Romance varieties, focalization is clearly distinct from topicalization. Indeed, the two processes have different syntactic correlates. First of all, focalization is an instance of quantificational movement (Rizzi 1997: 290-291) and this quantificational nature determines several syntactic differences with respect to topicalization. The presence of a resumptive clitic typically characterizes topicalization $(1 \mathrm{a}, \mathrm{b}),{ }^{2}$ whereas clitic resumption is incompatible with focalization $(1 \mathrm{c}, \mathrm{d})$. Fronted focus constituents give rise to Weak-Crossover effects (2b), while topics do not (2a). In addition, bare quantifiers can be focalized $(3 \mathrm{c}, \mathrm{d})$ but not topicalized $(3 \mathrm{a}, \mathrm{b})$, and focalization seems to be subject to a uniqueness restriction whereby there can only be one focus per sentence (4b). It is well known, on the contrary, that more than one topic can appear in a sentence (4a). One last difference involves wh-phrases. Topics are compatible with wh-phrases (5a), whereas foci are not (5b), precisely because they target the same position in the left periphery of the sentence (Rizzi 1997): ${ }^{3}$

2. Clitic resumption in Italian is only obligatory in conjunction with dislocated direct objects and partitive complements (cf. Benincà 1988, Cinque 1990). For an overview of the apparent cases of optionality and the associated variation, see Cruschina (2010b).

3. This generalization too needs clarification. It only holds for root interrogative clauses, inasmuch as foci and wh-phrases are compatible in embedded interrogatives (cf. Rizzi 2001). 
(1). a. Il tuo libro, lo ho comprato. the your book it.CL have.PRES.1SG buy.PP

'Your book, I bought it.'

b. * Il tuo libro, ho comprato $t$. the your book have.PRES.1SG buy.PP

c. * IL TUO LIBRO lo ho comprato (non il suo). the your book it.CL have.PRES.1SG buy.PP not the his

d. IL TUO LIBRO ho comprato $t$ (non il suo). the your book have.PRES.1SG buy.PP not the his 'It is your book I bought (not his).'

(2) a. Gianni, sua madre lo ha sempre apprezzato.

John his mother him.CL has always appreciated

'Gianni, his mother always appreciated him.'

b. ?? GIANNI sua madre ha sempre apprezzato $t$ (non Piero). John his mother has always appreciated not Piero 'His mother has always appreciated John (not Piero).'

(3) a. * Nessuno, lo ho visto. no-one him.CL have.PRES.1SG see.PP

b. * Tutto, lo ho fatto. everything it.CL have.PRES.1SG do.PP

c. NESSUNO ho visto $t$. no-one have.PRES.1SG see.PP 'I saw nobody.'

d. TUTTO ho fatto $t$. everything have.PRES.1SG do.PP 'I did everything.'

(4) a. Il libro, a Gianni, domani, glielo darò the book to John tomorrow to-him.CL-it.CL give.FUT.1SG senz'altro. without-other

'Tomorrow I will give the book to John for sure.'

b. * A GIANNI IL LIBRO darò (non a Piero, l'articolo). to John the book give.FUT.1SG not to Piero the-article 
(5)
a. A Gianni, che cosa gli hai detto? to John what thing to-him.CL have.PRES.2SG tell.PP 'What did you tell John?'
b. * A GIANNI che cosa hai detto (, non a Piero)? to John what thing have.PRES.2SG tell.PP not to Piero

The position of the focus may also differ according to the focus type, whether it is a contrastive focus (CFoc) or an informational focus (IFoc). Both types behave similarly with respect to the properties that distinguish focalization from topicalization, which confirm their operator quantificational nature. Nevertheless, they differ with respect to other syntactic properties. More specifically, the evidence for a distinction between CFoc and IFoc comes from their distribution, namely, from the different position they may occupy within the clause in a specific variety. In those varieties where both CFoc and IFoc can appear in the left periphery of the sentence (e.g. Sardinian and Sicilian), other differences include a requirement of adjacency to the verb and a general incompatibility with embedded contexts: only IFoc need be adjacent to the verb and proves marginal, if not completely ungrammatical, in the left periphery of embedded clauses.

The distinction between focalization and topicalization in Modern Romance is generally accepted and has received a great deal of attention. Let us thus consider in more detail the distinction between IFoc and CFoc and, in particular, the distributional variation related to focus type. As will be shown in the next section, special attention is to be given to the notion of contrast and its significance in the designation of focalization as syntactic movement.

\subsection{Contrastive Focalization}

The evidence from Romance suggests the existence of a focus position in the left periphery of the sentence specialized in licensing CFoc, namely, for fronted constituents characterized by a contrastive interpretation. This situation appears to hold true for most Romance languages (cf. Benincà 1988, Rizzi 1997, Frascarelli 2000, Belletti 2004, for Italian; Zubizarreta 1998, 1999, Zagona 2002, for Spanish; Motapanyane 1998, Alboiu 2002, for Romanian; Quer 2002 for Catalan; cf. also López 2009):
(6) A GIANNI l'ho dato (non a Piero). Italian
to Gianni it.CL-have.1SG give.PP not to Piero
'I gave it to John (not to Peter).' (Belletti 2004: 17)

(7) MANZANAS compró Pedro (y no peras). Spanish apples buy.PAST.3sG Peter and not pears

'Pedro bought apples (and not pears).' (Zubizarreta 1999: 4239) 
(8) Ieri,

la Bucureşti, Paul MAŞINĂ voia

să-şi Romanian

yesterday in Bucharest Paul car

want.PAST.3SG to-REFL.CL

cumpere (nu televizor).

buy.SUBJ.3SG not television

'Yesterday, in Bucharest, Paul wanted to buy a car, not a tv set.'

(Motapanyane 1998: 228)

The robustness of this evidence has been used as the empirical basis for the claim that FF in Romance is to be exclusively related to contrast (cf., e.g., López 2009). The notion of contrast, however, is not uncontroversial. This term has been used with different meanings and nuances in the literature, including the studies on focus. It has been defined according to different criteria, and a variety of types and degrees of contrastiveness have been identified (cf. Molnár 2002). Some studies have taken contrast to be a pragmatic product deriving from the discourse and from the context of communication, playing no role in the definition of the linguistic properties of focus (Lambrecht 1994, Rooth 1992, Brunetti 2004). Others, however, have clearly shown that contrast is an informationstructure notion that has a direct impact on linguistic expressions (É. Kiss 1998, Zubizarreta 1998, Bocci 2009, Vilkuna 1995, Vallduví and Vilkuna 1998, Molnár 2002, Frascarelli and Hinterhölzl 2007). Moreover, contrast has been viewed as the key factor in the distinguishing between different types of focus, in particular between CFoc and IFoc. In this regard, this notion must be understood as contrast against an explicit set of alternatives, which must be limited, in the sense that they have to be contextually given or explicitly mentioned in the discourse. In accordance with this definition, the contrastively-focalized constituent is to be interpreted as belonging to a given set of alternatives, out of which it is selected to the exclusion of the others. CFoc typically denies or corrects the value of the alternative, assigning a different value (cf. the examples (6-8) above). The main characteristic of corrections is that, for them to be felicitous, there must be an 'antecedent' in a previous asserted proposition such that the corrective claim and the contextually given alternative are incompatible (cf. van Leusen 2004). Thus, CFoc requires a highly specific context and introduces a special conversational move which is only partially related to focalization. On the other hand, IFoc is purely informational and not so dependent on the previous assertion. It introduces a new information constituent into the discourse, which is highlighted with respect to the background. It may also evoke a set of alternatives, but this will be an either open or contextually restricted set, with no direct contrast with explicit alternatives (cf. Cruschina 2008). ${ }^{4}$

The generalization that Romance focalization is bound to contrast encounters an initial problem if we look at the variation in Romance. Some varieties such

4. Two distinct positions encode CFoc and IFoc in the CP. This claim is supported by the syntactic differences that will be discussed below, but independent evidence is also provided by prosodic analysis of the two types of focus (cf. Bocci 2009). In the examples, capital letters are used for CFoc and bold is used for IFoc. 
as French (Lambrecht 1994, Belletti 2004) and Turinese (Paoli 2003) appear not to activate any left-peripheral focus position, not even for CFoc. ${ }^{5}$ The following examples are from Turinese (Paoli 2003: 161):

(9) a. Gioann a l' ha catà IL GELATO, nen la torta John SCL L has bought the ice-cream not the cake 'It is the ice-cream that John has bought, not the cake.'

b. * IL GELATO a l' ha catà Gioann, nen la torta the ice-cream SCL L has bought John not the cake

(10) a. Giòrs a l' è andàit $\mathrm{AL}$ CÌNEMA, nen al teatro George SCL L be.PRES.3SG go.PP to-the cinema not to-the theatre 'It is to the cinema that George has gone, not the theatre.'

b. * AL CÌNEMA a l'è andai Giòrs, nen al teatro to-the cinema SCL L be.PRES.3SG go.PP George not to the theatre

In fact, French and Turinese do not contravene the generalization above, since FF is entirely absent. In these varieties, focalization exploits a different, clause-internal, focus position, in the shape of postverbal focalization (cf. 9a, 10a) or cleft-sentences (11b, 12) (cf. Belletti 2005):

(11) a. Qui est parti / a parlé? who is left / has spoken

'Who left / spoke?'

b. C'est Jean (qui est parti / a parlé) it-is John who is left / has spoken 'It's John (who left / spoke).'

(12) C'est JEAN qui a parlé, pas Paul. it-is John who has spoken not Paul 'It's John who spoke, not Paul.'

These examples show that in Turinese $(9,10)$ and in French $(11,12)$ the high focus projection is not active for focalization of any kind. Rather, the clauseinternal focus position is employed to express new information focalization (i.e. IFoc), on a par with focalization conveying contrastiveness (i.e. CFoc). This is the position identified by Belletti $(2001,2004)$ in the left periphery of $v$, which

5. According to De Cat (2007: 2-3), some limited cases of contrastive FF are possible in colloquial French, but these are subject to «strict contextual restrictions», as well as to constraints on the syntactic category of the fronted element. 
comprises an array of topic and focus projections similar to the left periphery of C (cf. also Poletto 2006, Drubig 2007). ${ }^{6}$ In the medieval period, during the phase identified as being syntactically V2, FF was much more productive across Romance (cf. Benincà 1983/84, 1995, 2006, Adams 1987, Fontana 1993, 1997, Roberts 1993, Ribeiro 1995, Torres Morais 1995, Vance 1997, Salvi 2000, 2001, 2004, 2010, Vanelli 1986, 1998, Ledgeway 2007, 2008, 2011), licensing not just CFoc, but also IFoc, i.e. fronted constituents with non-contrastive, informationally salient interpretations, in a left-peripheral position. Recent studies have added new aspects to this scenario. It has been shown that non-contrastive FF, typical of Medieval Romance, is still frequently attested today in varieties such as Sardinian and Sicilian. Moreover, it has been observed that even in those modern Romance varieties that do not permit fronting of informationally new, noncontrastive constituents, other types of non-contrastive fronting are allowed, such as fronting of indefinite quantifiers and quantified phrases (QP-Fronting), ${ }^{7}$ and fronting of constituents in sentences with an exclamative nuance (often related to surprise or unexpectedness) (Quer 2002, Cruschina 2008, Brunetti 2009). ${ }^{8}$ Before discussing the properties of focalization in Old Italo-Romance, in the next section we will consider non-contrastive focalization in Modern Italo-Romance, in Sardinian and Sicilian in particular.

\subsection{Non-contrastive Focalization}

As already stated, Sardinian and Sicilian are unusual within the Romance languages in not requiring any contrastive interpretation for FF to apply. Accepting the distinction between IFoc and CFoc, a distinction that has been widely acknowledged in the literature, albeit not wholly uncontroversially (cf. for example Brunetti 2004), we observe that FF in Sicilian and Sardinian is possible with both types of focus (cf. Cruschina and Remberger 2009):

6. In reality, Belletti (2004) suggests that the two focus projections are specialized for the type of focus: the left peripheral projection licenses CFoc, while the clause-internal projection is dedicated to IFoc. A full parallelism of the two peripheries is instead proposed in Poletto (2006) and Drubig (2007).

7. Quer (2002) points out that many similarities exist between QP-Fronting and FF (cf. also Cinque 1986). These similarities may be due to the focal nature of quantifiers or to the requirement for them to be fronted for scope and interpretive reasons. In those varieties that do not exhibit generalized non-contrastive FF, it could well be that quantifiers target a distinct position in the left periphery, as independently shown by Poletto (2000).

8. Another type of fronting, which however belongs to a specific style and is restricted to a high register of Italian, is the Anaphoric Fronting (Anteposizione Anaforica), discussed in Benincà (1988) and Benincà and Poletto (2004), whose function is that of creating a textual connection between the fronted constituent and a constituent already mentioned in the discourse, usually through a demonstrative or an adjective such as stesso, uguale 'the same'. This operation is also analysed in Cinque (1990) and Cardinaletti (2009) under the name of Resumptive Preposing. 
(13) a. Iddu picciliddu è.

Sicilian

he child be.pres.3sg

'He is a child.'

b. A frevi aju.

the fever have.PRES.1SG

'I have a temperature.' (Rohlfs 1969: 323)

(14) a. Maláidu ses?

sick be.PRES.2SG

Sardinian

'Are you sick?' (Jones 1993: 355)

b. Custu libru appo lessu.

this book have.PRES.1SG read.PP

'I read this book.' (Jones 1988: 185)

Although, in principle, in Sicilian and Sardinian any syntactic category may undergo focalization to the left periphery of the sentence, FF proves more common especially (but not exclusively) with quantifiers (15), predicative categories (13a, 14a, 15, 16), and complements of lexical have (13b, 17):

(15) a. Nenti jè

nothing be.PRES.3sG this

chissu!

Sicilian

'That's nothing.'

b. Troppu grassu est Juanne.

Sardinian

too fat be.PRES.3sG Juanne

'Juanne is too fat.' (Jones 1993: 18)

(16) a. Sissi, cuntenti sugnu!

Sicilian

yes glad be.PREs.1sG

'Yes indeed, I am glad!'

b. Tattaresu fiat.

Sardinian

from-Sassari be.IMPF.3SG

'He was from Sassari.' (Mensching and Remberger 2010: 262)

(17) Ragiuni aviti!

Sicilian

reason have.PRES.2PL

'You are right!'

(18) A domo mea venis.

to house my come.PRES.2SG

Sardinian

'You come to my house.' (Jones 1988: 185)

Moreover, FF is frequently found in answers to questions, and in declarative and interrogative sentences with an exclamative flavour: 
(19) a. Na casa s' accattà!

Sicilian

a house REFL.CL buy.PAST.3SG

'He bought a house!'

b. U suli niscì!

the sun go-out.PAST.3sG

'The sun came out!' (Cruschina 2006: 371)

c. Proendi esti!

rain.GER be.PRES.3SG

'It's raining!' (Lepori 2001: 72)

(20) a. Chi viglianti sì?

INT awake be.PRES.2SG

'Are you awake?'

b. Vossia chi dutturi jè?

yOu.POL INT doctor be.PRES.3SG

'Are you a doctor?' (Cruschina 2006: 372)

c. Comporatu l' as?

Sardinian

buy.PP it.CL have.PRES.2SG

'Did you buy it?'

d. Emmo, comporatu l' appo.

yes buy.PP it.CL have.PRES.1SG

'Yes, I did buy it.' (Jones 1993: 355)

The fronting of these constituents is more common in sentence types strongly associated with focus, such as copular and existential sentences, whose function is to introduce new referents or new properties into the discourse. As Lambrecht (1994: 179) notes, the discourse function of 'existential' sentences is «to introduce the NP referent into the discourse world of the interlocutors by asserting its PRESENCE in a given location»:

(21) a. A cuscina Pina c'è, c' u maritu.

Sicilian the cousin Pina there.CL-is with the husband 'There is cousin Pina, with her husband.'

b. I picciliddi ci sunnu, ca jocanu p'a strata. the children there.CL are that play.PRES.3PL for-the street 'There are the children, who play on the street.'

c. Trona forti ci foru, parsi na tempesta. thunders strong there.CL were, seem.PAST.3SG a storm 'There was a loud thunder, it seemed like a storm.' 
(22) a. Frittu meta b'at!

Sardinian

cold much there.CL-has

'It is very cold.' (lit. There is much cold)

b. Zente meda b'at?

people a-lot there.CL-has

'Are there a lot of people?' (Pittau 1991: 142)

c. Puru is parentis suus ci funt?

also the relatives his there are

'Are his relatives also there?' (Sa-Limba 1999-2010)

A straightforward relationship between syntactic marking and discourse properties (i.e. the information structure of the sentence) is thus guaranteed by the syntactic operation FF. This operation determines a peculiar word order characterized by the fronting of a constituent to the left of the verb, and is to be analysed as involving movement to a dedicated functional projection FocP in the left periphery of the sentence (Benincà and Poletto 2004, Cruschina 2006, 2008, 2010a, Bentley 2007). We therefore assume that this dedicated position is responsible for the fronting of non-contrastive focus constituents. Besides, it is associated with syntactic and interpretive properties that distinguish it from the contrastive FocP identified by Rizzi (1997) for Italian. Nonetheless, FF in Sicilian and Sardinian is also possible with CFoc, as in the following examples from Sardinian (Mensching and Remberger 2010: 263) and Sicilian, respectively:

(23) A CASTEDDU soe andadu, no a Nùgoro.

Sardinian

to Cagliari am gone not to Nuoro

'It was to Cagliari that I went, not to Nuoro.'

(24)

UN LIBBRU ci detti $\quad$ no nu giornali). Sicilian
a book to-him.CL give.PAST.1sG not a newspaper
'It was a book that I gave him, not a newspaper.'

At this point we need to make a clarification about the interpretive properties of IFoc or what we have generally called non-contrastive focalization. We defined IFoc as being purely informational, introducing a new information constituent into the discourse. Being characterized as the most salient constituent in the sentence, however, IFoc tends to take on a variety of possible pragmatic effects. These contextual effects are created by the interplay between the new information provided by the focus and the old information already available to the interlocutors (Cruschina 2008). ${ }^{9}$

9. In other cases, special interpretations seem to be bound to an illocutionary operator. For instance, in interrogative and declarative sentences, (non-contrastive) FF in both Sicilian and Sardinian is often associated with a special interpretation, such as the expression of new and unexpected information, and/or an interpretation of verum - conveying emphasis on the truth-value/polarity of the 
IFoc and CFoc can never co-occur, and this fact may suggest that they both move to one and the same focus position within the left periphery. However, there are good reasons to believe that these two types of focus actually target different positions. More specifically, we can view the part of the left periphery dedicated to the encoding of focus as comprising of two independent and distinct positions, one for CFoc and one for IFoc (Benincà 2001, Benincà and Poletto 2004, Cruschina 2006, 2008, 2010a). This distinction is supported by numerous studies highlighting prosodic differences (Zubizarreta 1998, Selkirk 2002, Nespor and Guasti 2002, Donati and Nespor 2003, Avesani and Vayra 2004, Bocci and Avesani 2006, 2008, Bocci 2008, 2009), but also by syntactic evidence (Cruschina 2006, 2008, 2010a, Bentley 2007). In Sicilian and Sardinian, varieties which permit the fronting of both types of focus, only CFoc, and not IFoc, is possible in embedded clauses: ${ }^{10}$

(25) a. Unu zogo cherzo chi mi donat.

a toy want.PRES.1SG that to-me.CL give.PRES.3SG

'I want him to give me a toy.' (Sa-Limba 1999-2010)

b. * Cherzo chi unu zogu mi donat.

want.PRES.1SG that a toy me.CL give.PRES.3SG

(26) a. Un cavaddu voli ca ci accatti.

a horse want.PRES.3SG that to-him.CL buy.PRES.2SG

'He wants you to buy him a horse.'

b. * Voli ca un cavaddu ci accatti. want.PRES.3SG that a horse to-him.CL buy.PRES.2SG

IFoc cannot undergo partial movement to an intermediate periphery and must move on to the left periphery of the matrix clause, as illustrated in (25a) and (26a) from Sardinian and Sicilian respectively. By contrast, CFoc can stay in the left periphery of a complement clause:

(27) Cherzo chi SU ZOGU mi donat, no sa machina. want.PRES.1SG that the toy me.CL give.PRES.3SG not the car

'I want him to give me the toy, not the car.'

proposition (cf. Jones 1993: 256, Mensching and Remberger 2010, Remberger 2010, Leonetti and Escandell Vidal 2009). Both interpretations give rise to the above-mentioned exclamative flavour (cf. Cruschina 2008, Cruschina and Remberger 2009), presumably deriving from the interaction of the focus with an exclamative operator sitting in a functional projection related to Person or speech features in the left periphery of the sentence (cf. Sigurðsson 2004).

10. The distinction between CFoc and IFoc is very clear to native speakers in terms of intonational differences. Although both types of focus bear the main stress of the sentence, CFoc has a more emphatic accent which prosodically isolates this element from the rest of the sentence, which in turn is intonationally flat. 

(28) Voli ca U CAVADDU ci accatti, no ssu want.PRES.3SG that the horse to-him.CL buy.PRES.2SG not that pupu. puppet 'He wants you to buy him the horse, not that puppet.'

Similarly, a strict adjacency requirement between the verb and the focalized constituent only holds for IFoc, and not for CFoc (Cruschina 2010a, Mensching and Remberger 2010), as revealed by the following oppositions in Sardinian and Sicilian:

(29) SOS DURCHES, a su pitzinnu appo comporadu, no sos puliches. the sweets to the child have.1sG bought not the fleas 'I bought sweets for the child, not fleas.' (Sa-Limba 1999-2010)
(30) A SALVO i chiavi i
detti, no a Pinu. to Salvo the keys them.CL give.PAST.3sG not to Pinu 'I gave the keys to Salvo, not to Pinu.' (Cruschina 2010a: 254)

The adjacency between fronted focus and verb is an essential condition for the grammaticality of FF structures in Sardinian, as generally acknowledged in the literature (cf. Jones 1988, 1993, among others). The same condition holds for Sicilian FF constructions. Nevertheless, this requirement can be violated when the fronted focus constitutes an instance of CFoc. In the examples (29) and (30), we observe that a constituent can intervene between CFoc and the verb. ${ }^{11}$

\section{The properties of Focalization in Old Italo-Romance}

Old Italian varieties, and Old Romance in general, are claimed to have exhibited a V2 word order (cf. Vanelli 1986, 1999, Salvi 2000, 2001, 2004, Benincà and Poletto 2004, Benincà 2006, Ledgeway 2007, 2008, 2011, among others). In these studies V2 is understood as a syntactic constraint which requires the finite verb in matrix clauses to move to the $\mathrm{C}$-position. This verb movement operation is generally, though not invariably, accompanied by a further movement rule which fronts one (or more) constituent(s) to the left periphery. The possibility of fronting one or more pragmatically-salient constituents brings about a situation in which the verb appears in positions other than second, such as the third or the fourth position of the clause (i.e. V3, V4, etc.) (cf. Benincà 2006, Poletto2006); this is incompatible with strict V2 grammar:

11. See Frascarelli (2005), Frascarelli and Puglielli (2008) for cross-linguistic evidence that «languages that realize Focus in a fronted position do not allow informational Focus in embedded C-domains» (Frascarelli 2005: 17-18). 
Old Italo-Romance (Benincà 2006: 69-70)

(31) a. [L'altre ami] [si] est la moiller.

the-other friend so is the wife

'The other friend is the wife.' (OPiem.; Serm. Sub., 238)

b. [A lè] [per tug li tempi] me rend e me consegno.

to her for all the times me surrender and me deliver

'I surrender and submit myself to her forever.' (OMilan.; Bonvesin, p. 163)

c. E [Pero Capel] [en la fiata] branchà uno uiger de pes

and Pero Capel immediately seized a hamper of fish

'And Pero Capel immediately seized a hamper of fish.'

(OVen.; Lio Mazor, p. 35)

d. [Allora] [questi] andò e ricombatté

then this went and fought-again

'Then he went there and began to fight again.' (OFlorent.; Novellino, 37)

e. [La figura piacente] [lo coro] mi dilanca

the figure pleasant the heart to-me wrenches

'The pleasant figure tears my heart.'

(OSic.; Scremin, 34: Jacopo da Lentini)

Moreover, the alleged verb movement operation is not always followed by the additional fronting step, and consequently the verb superficially occurs in the first position. V-initial orders are indeed very common in Old Italo-Romance, as witnessed by the following examples:

Old Italian (Il Novellino)

(32) a. Andar li ambasciadori, e rinunziaro e raccontaro ciò went the ambassadors and related and told what ch'aveano veduto et udito.

that-had seen and heard

'The ambassadors went away, and related and told what they had seen and heard.'

b. Andò a questo suo fratello frate per ragionare co llui. went to this his brother friar for reason with him 'He went to his friar brother to reason with him.'

c. Tolsero alquante galee, e tolsero conducitori.

Seized some galleys and seized sailors

'They seized a number of galleys, and they seized sailors.' 
(33) a. Reconta sancto Gregorio che uno iurno ... tells saint Gregory that one day 'Saint Gregory tells that one day ...'

b. Canoscu como eo so ... know.1sG how I am 'I know how I am ...'

c. Adcomenza adunca ad recuntare begins then to tell 'He then begins to tell.'

Within the V2 accounts of Old Italo-Romance syntax, this variation does not invalidate the V2 generalization, which consistently holds, insofar as the verb is invariably assumed to have moved to the C-position, irrespective of its superficial position. The orders other than V2 are ascribed to the number of the additional fronting operations, which can result in the fronting of none, one, or more constituents to the left of the verb.

At this point it is natural to wonder why the verb should invariably move to the $\mathrm{CP}$ and what the triggering factor for this movement should be. The range of possible orders (i.e. V1, V2, V3, V4, etc.) weakens the parallelism with strict Germanic $\mathrm{V} 2$ languages, where V2 is the result of a constant structural requirement. Turning now to the nature of the fronted constituents, we will see whether we can find a solution to this puzzle.

\subsection{The nature of the fronted constituents}

In Old Italo-Romance, the preverbal position is not a privileged subject position but rather constitutes a pragmatically salient position for topicalized or focalized constituents, potentially available to all syntactic categories. In general, the discourse may help to distinguish between topicalization and focalization. Topicalization of arguments other than the subject occurs when the referent denoted by the topicalized constituent is known, either because it has already been introduced in the discourse or because it is identifiable on the basis of the previous context (34). When it is not linked to old or known information, and is hence not retrievable from the context, it is more likely that the fronted constituent is adding new information to the discourse. In these cases, we are dealing with focalization $(35 \mathrm{a}, \mathrm{b}):{ }^{12}$

12. Examples (34)-(36) are discussed in Vanelli (1999: 236-237). As in this work, the fronted constituents, as well as the resumptive clitics in (36), are marked in italics. A topic reading of the fronted constituent become more evident in the case of list or contrastive interpretations (cf. Benincà and Poletto 2004, Frascarelli and Hinterhölzl 2007, for more details of these types of topic interpretation in Modern Italian). 
Old Italian

(34) Ma v'ha

ancora di quelle cose le quali elli non vide, bu there.CL-has still of those things the which he not saw ma udille da persone degne di fede, e però le but heard-them.CL from people worth of trust and however the cose vedute dirà di veduta e l'altre per udita. things seen say.FUT.3SG of see and the-others for heard 'There is also much here that he has not seen but has heard from men of credit and veracity. We will set down things seen as seen, things heard as heard.' (Milione, I 3)

Old Italian

(35) a. Maestro, tu se' di grande savere, e credo che Master, you are of great knowledge and believe.1sG that di tutte le cose t'intendi. of all the things you-know-about

'Master, you are very knowledgeable, and I believe you know about everything.' (Il Novellino, II 27-28)

b. [...] lo quale Roboam avea nome. the which Roboam had name

'[...] who was called Roboam.' (Il Novellino, IV 22)

The distinction between topicalization and focalization, however, it is not always clear-cut. For obvious reasons we cannot rely on prosodic clues, but even when syntax is considered it is not always possible to test all the aspects that are relevant in the modern languages. A first problem concerns clitic resumption. In modern Italian, clitic resumption is related to topicalization. By contrast, in Old Italian topicalized constituents were not always connected to a resumptive clitic attached to the verb $(34,36)$ :

Old Italian

(36) Lo vino fanno di riso con ispezie molto buono. La moneta the wine make.3PL of rice with spices very good the coin hanno d'oro e di porcellane. have.3PL of-gold and of porcelain 'They make very good wine with rice and spices. Their coins are made of gold and porcelain.' (Milione, II9 9-10)

As pointed out by Vanelli (1999: 236), Modern Italian would use clitic resumption in the equivalent sentences: ${ }^{13}$

13. According to Benincà $(2006,2010)$, in Old Italian the resumptive clitic is obligatory when the fronted object is not adjacent to the verb. However, adjacency to the verb and lack of clitic may 
(37) Lo vino lo fanno di riso [...]. La moneta ce l'hanno d'oro [...]. the wine it.cl make.3PL of rise the money CL it.CL-have.3PL of-gold

In light of this characterization, it emerges that a fronted constituent with no clitic resumption could be ambiguously interpreted as either topic or focus. As argued, discourse and contextual considerations could often favour one interpretation over the other, but this is not always the case. Recent studies have observed some similarities between FF in Old Italo-Romance and FF in some modern Italo-Romance varieties. A comparison between modern and old languages could shed new light on FF in Old Italo-Romance and could further help to disambiguate the topic from the focus interpretation. Benincà and Poletto (2004: 58) point out that in regional Southern Italian, «one of the typical properties of V2 Medieval Romance appears to some extent maintained. Informational Focus is found in all of these varieties in sentence initial position». This is true of medieval Italo-Romance varieties (38) and Sicilian Italian: ${ }^{14}$

(38) a. Ço dis-le plusor fiade

Old Venetian

this said-he many times

'He said this many times.'

b. Una fertra fei lo reis Salomon

a sedan-chair made the King Salomon

Old Piedmontese

'King Solomon made a sedan chair.'

(39) a. Un libro comprasti?

Sicilian Italian

a book buy.PAST.2SG

'Did you buy a book?'

b. Antonio sono.

Antonio be.PRES.1SG

'It's Antonio.'

Following this suggestion (see also Vanelli 1986, 1999, Poletto 2006, Ledgeway 2011, Salvi 2011), we thus defend the idea that FF targets an operator position in

also correlate with topicalization. A topic may well occur immediately before the verb and lack clitic resumption (cf. 36). Sometimes the focus position would be occupied by elements such as 'sì' (cf. also Ledgeway 2008 on the nature of this element). If the fronted object is separated from the verb by this element, then clitic resumption is required. Vanelli $(1986,1999)$ noticed other general properties associated with topicalization with clitic resumption. First, the subject typically appears in a preverbal position; whereas, when the resumptive clitic is missing, the subject is either absent or in a postverbal position. In addition, in topicalization configurations with clitic resumption the dislocated constituent is generally 'heavy'.

14. By Sicilian Italian we mean the regional variety of Italian spoken in Sicily. Evidently, the main peculiarities of this variety of Italian are due to the influence of the underlying dialect, i.e. Sicilian proper. See also Benincà's (2004: fn.15) remark according to which it «seems that some southern Italian varieties, such as Sicilian or Sardinian, are still more similar to old Romance in the pragmatic interpretation of syntactic Focus.» 
the left periphery of the sentence and is not subject to specific interpretative constraints, as it is in Modern Italian; this position simply hosts the unmarked focus of the sentence, namely, IFoc. What about CFoc? We saw that in the group of modern Italo-Romance varieties where FF of both types of focus is possible, CFoc is involved in a distinct syntactic operation. It is therefore natural to ask whether this operation was possible in Medieval Italo-Romance. In fact, in the old texts there are no clear and unequivocal cases of CFoc-fronting, i.e. fronting of an element which is explicitly contrasted with another element present in the discourse (cf. Vanelli 1986). A contrastive nuance is present with the focalization of constituents such as quantifiers or degree modifiers (both adjectives and adverbs) that, for lexical and semantic reasons, give rise to a scalar contrast when marked and emphasized by FF:

Old Italian

\author{
(40) a. Maestro, di grande scienza ti credo. \\ master of great science you.CL believe.PRES.1SG \\ 'Master, I consider you of great knowledge.' (Il Novellino, II 45) \\ b. molti drappi di seta fanno [...]. \\ many cloths of silk do.PRES.3PL \\ 'They make many silk cloths [...].' (Milione, 147-3)
}

The meaning of the fronted constituent in these examples entails a dimension of gradualness or scalar quantity. Although prima facie these cases could be assimilated to CFoc, in reality they do not match the definition of contrast adopted for Modern Romance, insofar as they evoke a set of possible alternative values along a dimension of gradualness which are not limited, nor are they explicitly mentioned in the discourse. The contrastive effects only obtain from the pragmatics, as they are inferred from their lexical meaning.

There are two possible explanations for this finding. We could hypothesize that CFoc-Fronting is absent from old written documents as it is a 'correction' strategy predominantly used in the spoken language. Still now, in modern Italian, CFoc-Fronting is mainly found in the spoken language, as well as in written texts that attempt to imitate oral forms. According to this explanation, therefore, both IFoc- and CFoc-Fronting were available in Old Italian, although their attestation has to reckon with diamesic considerations. Alternatively, it could be said that CFoc-Fronting arose and developed at a later, if not recent, stage. In this account, the distinction between IFoc and CFoc would be further confirmed by diachronic divergence. In the absence of evidence in favour of the former hypothesis, we subscribe to the latter, especially in light of the comparative evidence examined above. By contrast, examples where no possible contrast can be detected in connection with FF abound in the texts and have been widely recognized in the literature. These are cases where it is not possible to perceive, even implicitly, a contrastive interpretation on the basis of the contest, nor is the fronted constituent a quantifier or a quantified phrase (cf. Vanelli 1986, 1999, among many others), but the fronted constituent simply qualifies as the focus of the sentence (41). Very 
frequently, the fronted constituent operates a textual connection to the previous discourse (42):

(41) Danaio non aveva da comperare da costui. Old Italian money not have.IMPF.3SG to buy.INF from this-man 'He didn't have any money to buy anything from this man.' (Il Novellino VIII II-I2)

(42) E questo vi conterà il libro ordinatamente. Old Italian and this to-you.cL tell.FUT.3sG the book in-order 'Our book will relate this to you plainly in due order.' (Milione, I 1)

In examples like (42) the fronted constituent typically involves a demonstrative element. The contextual connection provided by these constituents does not prevent them for being interpreted as foci. These cases should therefore also be analysed as instances of FF.

\subsection{Synchronic variation and diachronic evidence}

We have seen that in Old Italian, unlike modern Italian, and similarly to modern Sicilian and Sardinian, there were no interpretive constraints on the fronted focus constituent. This provides an explanation for the greater frequency with which FF occurs when compared to the modern language. However, many studies (Benincà 1983/84, Vanelli 1986: 266-170) point out that SVO is still the predominant word order in Medieval Italian and that V2 is just a discourse-marked option in a prevalently SVO language. At this point an obvious question is whether Old Italian and other old Italo-Romance varieties exhibit properties typical of the FF found in Modern Sicilian and Sardinian. A close comparison of the characteristics of FF can be useful in providing an answer. First of all, we can take as a starting point the observation that in both groups of languages, old Italo-Romance varieties on the one hand, and Sardinian and Sicilian on the other, FF is a discourse-related operation that creates a marked order, as opposed to instantiating the most frequent, if not basic, word order. Moreover, if we consider the structures and the syntactic categories that, for scope or interpretive reasons, are more amenable to focalization, we notice certain analogies between the old and the modern varieties. As described in $\S 2.2$, FF in modern Sardinian and Sicilian mainly occurs in copular sentences, existential constructions, and interrogative structures. In addition, FF mostly, albeit not exclusively, involves complements of lexical have, quantifiers and quantified phrases, as well as predicates, and, in particular, predicative modifiers (adjective and adverbs, cf. (43)). Few studies have undertaken a detailed investigation of the types of elements most frequently fronted in Old Romance. As already mentioned, one such study is Vanelli (1999), where it is observed that gradient predicatives and quantifiers or quantified phrases are among the most commonly fronted elements in Old Italian (44). Similar examples are found in other Italo-Romance varieties (45) (from Ledgeway 2007: 131-132): 
(43) a. Meglio èe che noi moriamo essendo franchi [...] Old Italian better is that we die being free 'It's better to die free [...].' (Tristano Riccardiano, I)

b. Signori, male avete fatto ... sirs badly have.2PL done 'Sirs, you have done badly ...' (Il Novellino, 131)

c. L'uno si fece avanti e disse: «Messere, io sono.» The-one REFL.CL made.2sG forward and said.3sg Sir I am 'One put himself forward and said: «Sir, it's me.»' (Il Novellino, 19)

(44) a. tre battaglie di campo ho poi fatte. Old Italian three battles of field have.PRES.1SG then do.PP 'I have then fought three battles.' (Il Novellino, XIXX 52-53)

b. Molte impromesse m'avete fatte [..]. many promises to-me.CL-have.PRES.2PL do.PP 'You have made me many promises [... ]' (Il Novellino, LIV 13-14)

Old Neapolitan

(45) a. nulla cosa puotti trovare che me fosse grato a preda. no thing could.1sG find that to-me.CL was pleasing to prey 'I could find nothing worthy of hunting.' (Destr. di Troya, 90.36-7)

b. e tutti le spetterravano per terra multo crudelmente. and all them.CL put-down.PAST.3PL for ground very cruelly 'and they cut then all down very cruelly.' (Destr. di Troya, 74.11)

These examples seem to confirm a parallelism between modern and medieval Italo-Romance varieties. The syntactic constituents most commonly fronted both in Modern Sicilian and in Modern Sardinian are quantifiers, fronted quantifiers, and predicative categories. Indeed, fronting of quantifiers or quantified phrases and fronting of predicative categories are rather frequent in Medieval Italian (Vanelli 1986, 1999, Poletto 2006). Interestingly, these are the last categories in connection to which FF, and fronting phenomena in general, are lost diachronically (cf. Roberts 2007, Biberauer and Roberts 2008, for negative quantifiers and quantified phrases in the history of the word order change from OV to VO in English, and Poletto 2006 for quantifiers and predicative categories in Medieval Italian). More recent studies have also emphasized the role of focalization in the placement of the subjects of existential constructions in Old Italo-Romance (cf. Ciconte 2010, Parry 2010): 
(46) a. speranza d'ensir no era.

Old Ligurian

hope of-getting-out not was

'There was no hope of escape.' (Anonimo genovese, 105: 14)

b. Uno re fu nelle parti di Egitto, lo quale avea ... Old Italian a king was in-the parts of Egypt, the which had 'There was a king somewhere in Egypt, who had ...

(Il Novellino, 134, 4: 1-2)

(47) a. E nullo peccato èy a lo mundo [...], che ... Old Neapolitan and no $\sin$ is in the world, [...] that 'and there is no sin in the world, [...], that ...' (Destr. di Troya, 252: 19-20)

b. tanti eranu ki tuctu lu campu trimava... Old Sicilian so-many were that all the field trembled 'There were so many that the whole field trembled ...'

(Istoria di Eneas, 119: 22-23)

Existential constructions, whose function is to introduce a new entity in the discourse (i.e. IFoc), normally present a fronted focus subject in Modern Sicilian and Sardinian as well (cf. 21-22 above). The possibility of finding the subjects of existential constructions in a preverbal position in medieval Italo-Romance varieties can therefore be connected to focalization.

To sum up, a close comparison of the interpretation, of the kinds of constituents typically fronted, and of the types of sentences most commonly featuring FF reveal a significant parallelism between modern and medieval Italo-Romance varieties. We can use this comparative evidence as a basis for the assumption that in Old Italo-Romance, when a constituent which is not connected to a resumptive clitic is fronted in contexts similar to those where FF typically occurs in the modern varieties, we can exclude a topic interpretation: we are dealing with contexts usually related to focalization and involving constituents which particularly lend themselves to a focus reading.

\subsection{The equivalence between FF and V2}

The particular syntax of Medieval Romance has been widely related to V2. ${ }^{15}$ Different analyses have been proposed, such as structural accounts of V2, particularly for Medieval French, whereby verb movement is associated with a structural requirement of the type found in Germanic (cf. Adams 1987, Roberts 1993 and Vance 1997; see also Ribeiro 1995 for Old Portuguese, and Fontanta 1993 for Old Spanish). In most studies on Old Italian, in addition to the structural nature of the

15. Several studies, however, have argued against a V2 analysis of Old Romance (cf. Kaiser 1999, 2002, Martins 2001). Others maintain that a distinction is necessary within Old Romance, insofar as some languages, namely Old Portuguese and Old Occitan, are assumed to be non-V2, whereas for others, such as Old French, it is proposed that they are (cf. Sitaridou 2006). 
verb movement, it is generally acknowledged that the initial constituent in V2 structures receives a focus or topic interpretation (Vanelli 1986, 1999, Benincà 1994, 2006, Salvi 2000, Ledgeway 2007). Here we claim that the V2 syntax of Medieval Italo-Romance should be linked to information structure and to the movement operations triggered by it (cf. Cruschina and Sitaridou 2010). According to this analysis, FF constitutes a means of instantiating the V2 syntax.

We have argued that in Old Italo-Romance the fronted focus constituent is an instance of IFoc. In section $\S 2.2$, it was also shown that in Modern Sardinian and Sicilian IFoc must be adjacent to the verb, while CFoc need not. This difference can be explained by resorting to a criterial analysis of verb movement. The constituent bearing the discourse-related feature must end up in a local checking configuration with the relevant functional head encoding the matching feature (cf. Rizzi 1996 [1991], 2006). Such a configuration is regulated by a family of principles, the Criteria, which require a Specifier/Head agreement relation between the criterial functional head and the corresponding features of the relevant class (i.e. Q, Top, Foc, R, ...), as illustrated in (48) from Rizzi (2006: 102):

(48) $\mathrm{XP}_{\mathrm{F}}$ and $\mathrm{X}_{\mathrm{F}}$ must be in a Spec-head configuration, for $\mathrm{F}=\mathrm{Q}$, Top, Foc, $\mathrm{R}, \ldots$

In the case of IFoc, the verb is the bearer of the relevant discourse (focus) feature, and for this reason must move to the head of the functional projection for the local Spec-Head criterial configuration to be met. Conversely, this kind of verb movement does take place with CFoc-fronting. According to Rizzi's (1997) analysis of CFoc in Modern Italian, the peripheral focus projection is inherently endowed with the relevant feature. ${ }^{16}$ Verb movement is therefore unnecessary for the required criterial configuration to be met. A clear result of the absence of verb movement is the lack of a strict requirement for the focus constituent and the verb to be adjacent. Under this analysis, therefore, in connection with IFoc the Focus Criterion is the trigger of both FF and verb-movement. In the case of CFoc, by contrast, only FF is driven by the Focus Criterion, and no verb movement occurs.

The adjacency requirement also holds for the old Italo-Romance varieties. As pointed out by Benincà $(2006,2010)$, for instance, if the fronted constituent is separated from the verb by an intervening constituent, clitic resumption becomes obligatory, and hence the fronted constituent unambiguously qualifies as a topic:

16. Non-contrastive FF has been independently linked to the verb. Horvath (1986), and subsequent studies, consider the verb to be the assigner of the focus feature in the syntax (cf. also Frascarelli 2000, among others). Molnár (2002) acknowledges that FF is 'verb-related' when not associated with a contrastive interpretation; for contrastive foci, instead, movement targets a sentence-initial position but is not necessarily verb-related. The existence of a tight relationship between focus and verb, as well as between wh-phrase and verb (Rizzi 1996), is thus generally acknowledged and recognized. However, a full explanation of its precise nature is still lacking. As for CFoc-Fronting, it could be claimed that the lack of such a relationship is due to its semantic and conversational characteristics, and its use for corrective purposes in a highly specific context, which make CFoc somehow different from focus proper (cf. §2.1.). 
(49) a. [Madonna per cui stava tuttavia in allegranza], [or] no la my.lady for whom was.1SG always in happiness now NEG her veggio né notte né dia. see.1SG neither night nor day 'My Lady, who always used to make me happy, I see her now neither day nor night.'

(OSic.; Schermin 88, Giacomino Pugliese)

b. [La vertude ch'ill'ave d'auciderme e guarire], [a lingua dir] the virtue that-he-has of-kill-me and heal, to tongue to-say non l'auso.

NEG it.dare.1SG

'I don't dare to tell the virtue he has to kill me and heal me.'

(OSic.; Schermin 88, Re Enzo)

According to this account, verb-movement is not the result of a structural requirement, but is rather a syntactic operation subordinate to FF, a product of the conditions imposed by the Focus Criterion. Further support in favour of this explanation comes from the fact that this analysis is the same analysis adopted for cases of «residual V2», most notably wh-movement, in modern languages with non-generalized V2 syntax (Rizzi 1996 [1991]). What triggers residual V2 in wh-structures? Rizzi (1996: 64) proposes that «the application of I-to-C movement in this and other similar cases is enforced in order to satisfy the Wh-Criterion, a general wellformedness condition on wh-structures.» Following this analysis permits a unified approach to closely related phenomena, both in synchrony and in diachrony, which would otherwise receive different treatments.

The Focus Criterion, however, does not account for all fronting structures in Old Italo-Romance. Besides focalization, topicalization is another common operation responsible for the fronting of constituents and, additionally, for verb movement. In the modern languages, we have no evidence to suggest that the verb may be the bearer of the topic feature and must therefore move to TopP to satisfy the Topic Criterion. Rather, a tacit assumption is that the head of TopP inherently possesses the relevant feature necessary to meet the criterion conditions. For Old Italo-Romance, and for Old Romance in general, enclisis on finite verbs has been related to topicalization and, in particular, to the lack of a focus constituent or operator in FocP. The traditional assumption is that enclisis derives from the movement of the verb to the CP. More specifically, Benincà (2006) provides a revised analysis of the classical Tobler-Mussafia law to account for enclisis, stating that clitics on the finite verb are enclitic not just when the verb is in the first position of the sentence, but when the inflected verb has moved to the left periphery of the sentence and the Focus/Operator position is empty. This analysis explains why the finite verb with an enclitic can be preceded by topics, but not by foci. According to Benincà, V-initial sentences are sentences which have a topic, although superficially null, and in which nothing is in the focus projection. This way the enclitic position of possible clitics conforms to the generalization that enclisis «is found 
when the verb has moved to $\mathrm{C}^{\circ}$, and the XP which immediately precedes it is not in the Focus field, but rather in the Topic field or in the Frame field» (Benincà 2006: 69). It clearly emerges from this analysis that topicalization appears to be another operation triggering verb movement, and hence instantiating V2. An additional head movement to a higher TopP, past the projection(s) hosting the clitic(s), is the causative factor of enclisis.

The question of the position of the clitics attached to the finite verb in Medieval Old Italo-Romance is undoubtedly very important, but is outside the scope of this paper. Here we would only like to point out that in this case too verb movement is related to an information-structure notion, namely, that of topic, and to the process of topicalization. More research on the precise trigger for the verb movement yielding enclisis is certainly required, in particular in order to gain a better understanding of its exact landing position. Whatever the answer, this seems to constitute the major difference between Medieval and Modern Italo-Romance, including Modern Sicilian and Sardinian, where there is no trace of the type of verb movement that causes enclisis on finite verbs.

To conclude this section, let us turn to the second syntactic difference between IFoc and CFoc in modern Sardinian and Sicilian: partial movement in embedded contexts. We saw that it is only CFoc that can stay in the left periphery of a complement clause, whereas IFoc cannot undergo 'partial movement' to an intermediate periphery and must move on to the left periphery of the matrix clause (Cruschina 2006, 2008, 2010a). Do we find anything similar in the medieval Italo-Romance languages? A precise comparison is difficult, but we can observe that in the same studies where the V2 hypothesis was first put forward in relation to Medieval Italo-Romance, it is acknowledged that marked word orders are less common in embedded clauses where the basic word order seems to be maintained (cf. Benincà 1983/84, 2006, Vanelli 1986, Benincà and Poletto 2004, Ledgeway 2007, among others). This is not unexpected from an information-structure perspective, since embedded clauses are usually «parasitic» on the matrix clauses and are consequently less subject to movement operations connected to topicalization or focalization (Benincà 2010: 28). Although embedded clauses only marginally exhibit orders other than the basic SVO, fronted constituents are not however invariably excluded in embedded contexts (cf. Benincà and Poletto 2004, Benincà 2006, Ledgeway 2007: 141$):{ }^{17}$

17. Even if marginal, the occurrence of FF in embedded contexts seems to contradict our generalization that, at least in Modern Sicilian and Sardinian, only CFoc can appear in the left periphery of a complement clause (cf. §2.2). It must be noted that in Medieval Romance fronting in embedded contexts predominantly occurs in complement clauses dependent on bridge-verbs, which have been claimed to have a 'full CP layer', similar or identical to that of matrix clauses (cf. Benincà 2006; see also Benincà and Poletto 2004, and Ledgeway 2007, 2008). Nevertheless, this does not fully account for the absence of exceptions of this type in the modern varieties. 
Old Italian

(50) Maestro, tu se' di grande savere, e credo che di tutte Master, you are of great knowledge and believe.1SG that of all le cose t'intendi. the things you-know-about 'Master, you are very knowledgeable, and I believe you know about everything.'

(Il Novellino, II 27-28)

Old Neapolitan

(51) La secunda cosa sì èy che con gran potere ne monstramo the secondo thing thus is that with great power REFL.CL show.1PL ad offensione et a destrictione de li nuostri nemice. to offence and to destruction of the our enemies 'The second thing is that we should attack and destroy our enemies with great power'

(Destr. di Troya, 70.2)

If viewed, with all possible caution, as a coherent subgroup of Romance Italian varieties that show properties similar to Old Italo-Romance, especially with respect to FF, Sardinian and Sicilian may be interpreted as conservative varieties in which important phenomena and oppositions that are hard to detect in other varieties can still be observed. The next question is therefore the following: are these residual properties of a medieval syntax? The evidence considered in the next section will provide us with the necessary data to draw the relevant conclusions.

\section{Old Sicilian and Old Sardinian}

Given the similarities with Medieval Italian, it would be natural to consider Sicilian and Sardinian as conservative varieties. After all, the claim that Medieval Romance varieties exhibited a V2 word order should extend to include Sardinian and Sicilian. FF in these varieties could be related to the medieval V2 principle and would then represent what is left of the V2 syntax of Medieval Romance (cf. Jones 1993: 336 for Sardinian). In the following sections we will examine the results of recent studies of word order in Old Sardinian and Old Sicilian. More specifically, we want to establish whether FF was already a widespread operation in Sicilian and Sardinian at that stage. If this was the case, then the attribute 'conservative' with respect to this property will prove appropriate. If not, we have to assume that FF in these two languages developed independently at a later point.

The usual problems with working with old texts arise here, and in fact to an even greater extent for these two languages. The number and variety of medieval texts in Sicilian and Sardinian are not readily comparable with those of other languages, such as Old Italian, for which a larger and more varied corpus of texts has allowed more detailed and contrastive analyses. However, in light of available 
results, we suggest that $\mathrm{FF}$, although present, was less frequent and might have actually developed after the medieval period both in Sardinian and in Sicilian.

\subsection{Word order in Old Sardinian}

The analysis of a corpus of Sardinian texts dating from the eleventh to the thirteenth centuries has led Lombardi (2007) to claim that in early Sardinian the most common word order is not V2. The verb is sometimes found in the second position of the sentence, but this does not represent the basic order, which is instead distinguished by the placement of the verb in first position, with the subject immediately following. VSO word order therefore appears to be the canonical word order of Medieval Sardinian:

(52) a. Coiuuait Urgekitana cun Jorgi Carta. marry.PAST.3SG Urgekitana with Jorgi Carta 'Urgekitana married Jorgi Carta.'

b. Vidit iuige custa carta et conosci ca [...] see.PAST.3sG judge this card and acknowledge.PAST.3sG that 'The judge saw this paper and acknowledged that [...]'

In the documents analysed, the finite verb shows a strong tendency to occur in clause initial position, as shown by the examples above. The V1 order characterizing Old Sardinian is sometimes altered for information structure reasons, as in cases of focalization. FF structures, however, while present, are on the whole rather sporadic, and mainly involve the subject of the sentence (53), although not exclusively (54):

(53) a. Tu nos mascasti ki la leuasti kene la peter. you us.CL offend.PAST.2SG that it.CL take.PAST.2SG without it.CL ask.INF 'You offended us as you took it without asking.'

b. abbatissa Maria las donait a ssocru meu, abbess Maria them.CL give.PAST.3SG to father-in-law my a donnikellu Ithoccur. to Sir Ithoccur

'Abbess Maria gave them to my father, to Sir Ithoccur.'

(54) a. E binia e cannabariu nos derun. and vineyard and hemp-field to-us.CL give.PAST.3PL 'They gave us both the vineyard and the hemp field.'

b. Et focu non se pongnat foras de uingna ortu and fire not IMP.CL set.PRES.3SG outside of vineyard garden ouer locu cungiatu.

or place closed

'And one should not set a fire outside of the vineyard, garden, or a closed place.' 
Lombardi's (2007) findings might reflect the stylistic conventions of the archive records and the legislative language of the Middle Ages. These are however the only available earliest Sardinian texts. It could well be that at this stage FF was in fact much more frequent in other registers, especially in the spoken language. Even so, according to Lombardi's (2007) results, it seems undeniable that V1 or VSO order was very common, if not the basic order, in early Sardinian.

\subsection{Word order in Old Sicilian}

Unlike in Sardinian, SVO is the predominant, or unmarked, word order in Old Sicilian (Cruschina 2008), as exemplified by the following sentences:

(55) a. Li parenti soy si facevano gabbo de ipso. the parents his REFL.CL do.IMPF.3PL mockery of him 'His parents used to make fun of him.'

b. Pietro sì adimanda ad sancto Gregorio [...]

Peter so ask.PAST.3sG to Saint Gregory

'And so Peter asked Saint Gregory.'

FF is indeed present, but is far from being as frequent or regular as in the modern language. When a clear FF structure emerges, whereby the preverbal constituent has an unambiguous focal nature, the constituents involved are mainly degree words, modifiers, and quantifiers or quantified phrases, but also constituents of different categories:

(56) a. e tando mi desplacea chisto mundo. and so-much to-me.CL displease.PRES.3SG this word 'and I disliked this world so much.'

b. grande gracia li fece Dio.

big grace to-him.CL do.PAST.3SG God

'God had great mercy on him.'

c. et multi persune so che ssi actraino

and many people know.PRES.1SG that REFL.CL attract.PRES.3PL

a la via de Dio.

to the way of God

'and I know that many people are attracted to the way of God.' 
(57) a. Chisto Unurato [...] ad tanta penitencia et abstinencia

this Unurato to much penitence and abstinence

sì se dede.

So REFL.CL give.PAST.3SG

'This Unurato devoted himself to so much penitence and abstinence.'

b. lu officiu de lu episcupatu ademplìa bene per soy

the office of the episcopate fulfil.IMPF.3SG well for his

boni custumi.

good customs

'He well fulfilled the role of bishop thanks to his good customs.'

The Sicilian data stem from a quantitative analysis of word order in the medieval Messinese text Libru de lu dialagu di Sanctu Gregoriu. Once again, the scarcity and the nature of Sicilian Medieval texts, most of which derive from ecclesiastic and religious documents, are not particularly indicative of other types of register or of the spoken language. On the basis of the few examples of FF found, however, it can be hypothesized that FF in Sicilian was already present in the medieval period, but subsequently underwent further developments. The data in (56) and (57b) show that adjacency between the fronted constituent and the inflected verb may be taken as evidence for a criterial condition on FF. However, compelling evidence for a full V2 system in this language is wholly lacking.

The marginal occurrence of FF may thus be taken as evidence for the hypothesis that FF in Medieval Sicilian and Sardinian was indeed present, but only to a limited extent, and probably developed as a productive construction at a later stage. ${ }^{18}$ Only a detailed analysis of post-medieval texts will allow us to confirm if this hypothesis is correct for each language, an investigation which we leave open for future research.

\section{Criterial analysis of Focalization: discourse-related features and functional projections}

Returning now to the parallelism between old and modern Italo-Romance varieties, we propose to extend the criterial analysis of focalization elaborated for modern languages (cf. Rizzi 1997, 2006; see also Cruschina 2008) to Medieval Italo-Romance, aiming to gain a better understanding of the principles and mechanisms behind word order change in diachrony. According to the criterial analysis

18. It is important to bear in mind that here we are only considering IFoc. It could well be that the difference in the frequency of occurrence between the medieval and modern stage only appears to be the case and is probably due to the fact that we are comparing medieval texts with the modern spoken language. The usual precautions when dealing with old texts and with diachronic comparisons should be applied to these considerations. No evidence is available for the existence of CFocfronting in Medieval Sicilian and Sardinian (cf. §3.1), while we have described the properties of such a structure in Modern Sicilian and Sardinian (cf. §2.2), where it is used as a corrective strategy requiring an explicit antecedent and not exclusively related to focalization (cf. §2.1). 
of focalization, the verb, which is the bearer of the focus feature, must move to the head of the functional projection FocP in the left periphery of the sentence for the local Spec-Head criterial configuration to be met. It is necessary to stipulate intermediate movement, which «is driven by features that are the purely formal counterpart of substantive criterial features» (Rizzi 2006: 111). In this model, two types of movement-triggering features are present: Substantive Criterial Features $\left(\mathrm{SCF}_{\mathrm{S}}\right)$, which are interpretable, and purely Formal Criterial Features $\left(\mathrm{FCF}_{\mathrm{S}}\right)$, which are uninterpretable. If a functional head is endowed with an SCF (the criterial probe), the XP bearing a matching criterial feature (criterial goal) will be attracted into its specifier. The relevant Criterion is thus satisfied by the local Spec-Head agreement.

On the other hand, if a functional head is endowed with an FCF, this head will attract the XP bearing the same feature into its specifier, but will fail to Agree with the XP and hence to value and deactivate its feature. Unlike in other languages, including Standard Italian, in Sicilian and in Sardinian $\mathrm{Foc}^{\circ}$ at the left periphery of the vP fails to value the active feature within its domain, because it lacks the relevant SCF. As a result, the constituent bearing the active and unvalued feature must raise to its specifier position, and hence to the specifier of the phase head (Rizzi 2006, 2009) to find an 'escape hatch' in order to avoid Transfer/Spell-out and remain accessible to the higher FocP in the higher phase. Here its active feature will be checked by the pertinent SCF. The criterial positions are therefore reached through successive-movement steps, satisfying locality requirements. Applying this model to Medieval Italo-Romance, we assume that in these varieties it is only the higher FocP which is endowed with an SCF and, consequently, the focus constituent has to move up to this position to have its focus feature valued. Here we are only concerned with IFoc, insofar as it has been shown that no genuine cases of CFoc have been found in Medieval Italo-Romance (cf. §3.1). ${ }^{19}$ This analysis is able to account for both the synchronic and the diachronic variation concerning the position of the focus constituent. Moreover, it provides valuable tools for an explanation of the word order changes associated with information structure. In recent studies, word order changes have been viewed as possible sources for processes of grammaticalization (cf. Fischer 2008, 2010). ${ }^{20}$ In our account, in particular, word order changes could be seen as related to the type of feature associated with the functional projection in question. An exploration of this line of argument is the subject of the next section.

The varied scenario that we find in Italo-Romance with respect to the position of the focus constituent can be explained in diachronic terms as the result of «some change in the realization/attraction property of functional heads, that is, a change in the lexicon» (Roberts and Roussou 2003:7). Discourse-related functional heads can be activated by the movement of a constituent (cf. Benincà and Poletto 2004,

19. An independent projection of CFoc is therefore missing in the representations (58) and (59) below.

20. As observed by an anonymous reviewer, the term 'grammaticalization' would not be appropriate to describe the change in the featural make-up of functional projections induced by word-order discussed here, as it cannot be understood with its traditional meaning which refers to changes from lexical to functional. The term 'reanalysis' is adopted instead. 
Benincà 2006, for Old Italian), according to the attraction property of the relevant functional projection. The ability to attract is in turn linked to the type of feature (substantive vs. formal) associated with the functional projection in question. In the majority of the modern Italo-Romance languages, however, with the exception of Sardinian and Sicilian, it seems that the left peripheral FocP has lost its attraction property and, as a consequence, the focus constituent moves to the clause-internal focus projection. This means that the lower FocP is now equipped with an SCF which is able to check the focus feature of the focus constituent rendering any further movement not only unnecessary, but impossible.

A change in the featural make-up of functional projections could be seen as an instance of word-order induced reanalysis. In her recent work, Fischer (2010) claims, and demonstrates through an ample set of data and inter-related phenomena, that the grammaticalization of functional projections does not have to be driven by a morphological trigger, but could also be the result of word order changes. Following this analysis, then, we assume that, as soon as different word orders are associated with specific information structures, and hence with specific interpretations, the left peripheral FocP stops being active. The deactivation of the higher FocP is therefore caused by word order changes, but at the same time it has significant repercussions on the word order alternations in the language and their relationship with the information structure. The speakers thus started associating focalization with the lower FocP, marking the focus constituent in a (superficially) postverbal position. This amounts to saying that the lower FocP is now able to check and value the corresponding feature on the focus constituent. In other words, this projection is now endowed with a SCF, as summarized in the following illustrations: ${ }^{21}$

(58) Medieval Italo-Romance

(and Modern Sardinian and Sicilian):

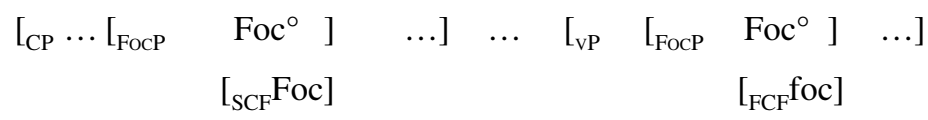

(59) Modern Italo-Romance

(except Sardinian and Sicilian):

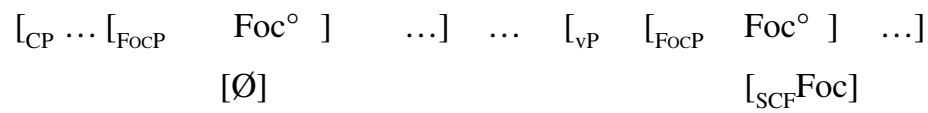

21. The wh-element in the interrogative sentence is considered to be the focus of the question (cf. Cruschina 2008 for discussion). In Italo-Romance varieties where the wh-element is fronted to the left periphery, we must thus assume that the higher $\mathrm{Foc}^{\circ}$ possesses a SCF focus feature in interrogative clauses marked by the feature Q:

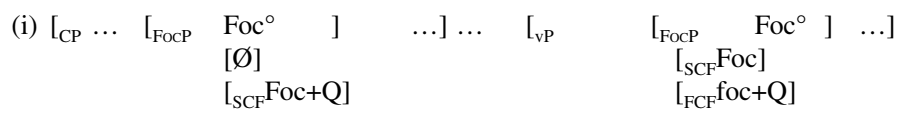

Evidently, this difference determined by the illocutionary force of the sentence does not concern Italo-Romance varieties with wh-in-situ (cf. Munaro 1999) where the higher FocP is invariably inactive. 
In light of this analysis, the requirement for the verb to move to the higher $\mathrm{Foc}^{\circ}$ in compliance with the criterial analysis in Sicilian and in Sardinian appears to be analogous to the V2 system fronting operation found in Old Italian, as well as in other Romance varieties. This demonstrates that, in Old Italo-Romance, V2 was related to information-structure and discourse features: verb movement is triggered by a criterial principle that strictly correlates the fronting of the focalized constituent to a specifier of the left periphery and the raising of the inflected verb to the corresponding head. Therefore, the loss of verb raising is not due to the loss of a V2 syntax, as often assumed, but to a process of reanalysis that led to the deactivation of the higher focus projection and its attraction properties. As a consequence, the syntactic reflexes of the Focus Criterion become less visible in terms of correspondences between information structure and word order.

\section{Conclusions and some final speculations}

In this study it has been shown that syntactic changes affecting word order in Old Italo-Romance are better understood in terms of their interaction and association with information structure. The fronting phenomena found in these old varieties have been generally attributed to functional projections related to discourse properties and, ultimately, to information structure. What has not been entirely clear in the literature is the factor that triggers verb movement in connection with such operations. Drawing from recent analyses of similar synchronic data, we have argued that the FF operation requires verb movement to satisfy a criterial configuration necessary for checking and valuing of features. FF is still found in Modern Sardinian and Sicilian. In these two varieties, both the fronting of the focus constituent and verb movement, visible in a strict adjacency requirement, are the direct effect of focalization operations related to discourse properties and information structure. Only with great difficulty could one suggest that a V2 system is present in these two modern languages. The diachronic change from preverbal focalization to postverbal focalization through the history of many Italo-Romance varieties, including Old Italian, is mirrored by the synchronic variation. In both cases, the explanation resides in the activation or deactivation and the parameterization of two focus projections within the clause: a higher, left peripheral FocP, and a lower, clause-internal FocP. We have analysed the activation of a functional projection as its association with an SCF, capable of valuing the focus feature on the moved constituent. Changes in this featural association, and hence in the activation of functional projections, have specific effects on the relationship between word order alternations and information structure.

The principal difference that remains between old and modern Italo-Romance varieties is enclisis on finite verbs. If compared to the modern data, the movement operation responsible for enclisis is left unexplained. An attractive hypothesis to account for this difference would be to claim that, unlike in the modern equivalents (cf. Frascarelli 2000, Cruschina 2008), in Medieval Italo-Romance the verb also participates in the information structure of the sentence and, as such, is independently subject to discourse-related syntactic operations. It could well be that the verb moves 
to a higher peripheral position to mark the predicate as the focus constituent of the sentence in a Topic-Comment (or predicate-focus in Lambrecht's (1994) terminology) configuration. Independent evidence for this hypothesis is found in the fact that only topic constituents can precede the finite verbs to which enclitics are attached. No focus constituents can appear in this type of sentence. This may be a consequence of the fact that the predicate itself is the focus, in obedience to a general principle that allows only one focus per sentence. In such an account, however, more details would be necessary to explain the position of the clitics. Irrespective of the precise analysis of this second kind of verb movement, it has been shown that, on the basis of the generalizations formulated by Benincà, the movement of the finite verb, responsible for enclisis, is still an operation related to information structure, to topicalization and to the absence of focus constituents in particular.

\section{Texts and Sources}

Old Florentine (OFlor.):

Novellino (1300): Favati, Guido (1970). Il Novellino. Genoa: Bozzi.

Old Italian:

(i) Il Novellino: Segre, Cesare (1976). Prosatori del Duecento. Trattati morali e allegorici. Novelle. Turin: Einaudi.

(ii) Milione: Bertolucci Pizzorusso, Valeria (1975). Marco Polo / Milione. Versione toscana del Trecento. Milan: Adelphi.

(iii)Tristano Riccardiano: Marti, Mario (1959). Tristano Riccardiano. In: Segre, Cesare; Marti, Mario (eds.), Prosa del Duecento. Milan-Naples: Ricciardi.

Old Ligurian:

Anonimo Genovese: Contini, Gianfranco (1960). Anonimo Genovese. In Gianfranco Contini (ed.), Poeti del Duecento, I. Milan-Naples: Riccardo Ricciardi.

Old Milanese (OMil.):

Bonvesin (1280): Contini, Gianfranco (1941). Le opere volgari di Bonvesin da la Riva. Rome: Società Filologica Romana.

\section{Old Neapoletan:}

Libro de la destructione de Troya: De Blasi, Nicola (1986). Libro de la destructione de Troya. Volgarizzamento napoletano trecentesco da Guido delle Colonne. Rome: Bonacci.

Old Piedmontese (OPied.):

Sermoni subalpini (Thirteenth century): Babilas, Wolfgang (1968). Untersuchungen zu den Sermoni subalpini. Munich: Hueber.

Old Sicilian (OSic.):

(i) Scremin, Maria Francesca (1984/85): La struttura della frase nella lingua poetica siciliana. University of Padua, Laurea thesis.

(ii) Libru de lu Dialagu di sanctu Gregoriu: Panvini, Bruno (1989). Iohanni Campulu. Libru de lu Dialagu di sanctu Gregoriu. Volgarizzamento siciliano del sec. XIV. Rubbettino (University of Catania: Collana di Studi di Filologia Moderna, 4). 
(iii)La istoria di Eneas: Folena, Gianfranco (1956). La istoria di Eneas / vulgarizata per Angilu di Capua. Palermo: Centro di studi filologici e linguistici siciliani.

Old Venetian (OVen.):

Lio Mazor: Levi, Ugo (1904). I monumenti del dialetto di Lio Mazor. Venice: Visentini.

Sardinian

Sa Limba (1999-2010). Electronic Corpus of the Postings to the Mailing List 'Sa-Limba.' Köln / Berlin [http://www.lingrom.fu-berlin.de/sardu/sa-limba.html].

\section{References}

Adams, Marianne (1987). Old French, Null Subjects and Verb Second Phenomena. UCLA, doctoral dissertation.

Alboiu, Gabriela (2002). The Features of Movement in Romanian. Bucharest: University of Bucharest Press.

Avesani, Cinzia; Vayra, Mario (2004). «Focus ristretto e focus contrastivo in italiano». In: Albano Leoni, Federico; Cutugno, Francesco; Pettorino, Massimo; Savy, Renata (eds.). Il Parlato Italiano. Atti del Convegno Nazionale (13-15 February 2003), B06, Naples: M. D'Auria Editore - CIRASS.

Belletti, Adriana (1999). «'Inversion' as Focalization and related questions». Catalan Working Papers in Linguistics 7: 9-45.

Belletti, Adriana (2001). «Inversion as focalization». In: Hulk, Aafke; Pollock, JeanYves (eds.). Subject Inversion in Romance and the Theory of Universal Grammar. Oxford/New York: Oxford University Press, pp. 60-90.

Belletti, Adriana (2004). «Aspects of the low IP area». In: Rizzi, Luigi (ed.). The Structure of IP and CP. The Cartography of Syntactic Structures, Vol. 2. Oxford/ New York: Oxford University Press, pp. 16-51.

Belletti, Adriana (2005). «Answering with a 'cleft': the role of the null subject parameter and the vP periphery». In: Brugè, Laura; Giusti, Giuliana; Munaro, Nicola; Schweikert, Walter; Turano, Giuseppina (eds.). Proceedings of the 'XXX Incontro di Grammatica Generativa'. Venice: Cafoscarina, pp. 63-82.

Benincà, Paola (1983/84). «Un'ipotesi sulla sintassi delle lingue romanze medievali». Quaderni Patavini di Linguistica 4: 3-19. Reprinted in Benincà, Paola (1994): La variazione sintattica. Studi di dialettologia romanza. Bologna: Il Mulino, pp. 177-194.

Benincà, Paola (1988). «L'ordine degli elementi della frase e le costruzioni marcate». In: Renzi, Lorenzo; Salvi, Giampaolo (eds.). Grande Grammatica Italiana di Consultazione, Vol. 1. Bologna: Il Mulino, pp. 129-194.

Benincà, Paola (1995). «Complement clitics in Medieval Romance: the Tobler-Mussafia Law». In: Battye, Adrian; Roberts, Ian (eds.). Clause Structure and Language Change. Oxford/New York: Oxford University Press, pp. 325-344.

Benincà, Paola (2001). «The position of Topic and Focus in the left periphery». In: Cinque, Guglielmo; Salvi, Giampaolo (eds.). Current Studies in Italian Syntax. Essays offered to Lorenzo Renzi. Amsterdam: Elsevier, pp. 39-64.

Benincà, Paola (2004). «The left periphery of Medieval Romance». Studi Filologici e Linguistici Online 2 (2): 243-297. 
Benincà, Paola (2006). «A Detailed Map of the Left Periphery of Old Romance». In: Zanuttini, Raffaella; Campos, Héctor; Herburger, Elena; Portner, Paul H. (eds.). Crosslinguistic Research in Syntax and Semantics: Negation, Tense and Clausal Architecture. Washington, DC: Georgetown University Press, pp. 53-86.

Benincà, Paola (2010). «L'ordine delle parole e la struttura della frase». In: Renzi, Lorenzo; Salvi, Giampaolo (eds.). Grammatica dell'italiano antico. Bologna: Il Mulino, pp. 27-75.

Benincà, Paola; Poletto, Cecilia (2004). «Topic, focus and V2: defining the CP sublayers». In: Rizzi, Luigi (ed.). The Structure of IP and CP. The Cartography of Syntactic Structures, Vol. 2. Oxford/New York: Oxford University Press, pp. 52-75.

Bentley, Delia (2007). «Relazioni grammaticali e ruoli pragmatici: siciliano e italiano a confronto». In: Bentley, Delia; Ledgeway, Adam (eds.). Sui dialetti italoromanzi: saggi in onore di Nigel B. Vincent [The Italianist 27, Special supplement ]. Norfolk: Biddles, pp. 48-62.

Biberauer, Theresa; Roberts, Ian (2008). «Cascading parameter change: Internallydriven change in Middle and Early Modern English». In: Eythórsson, Thórhallur (eds.). Grammatical change and linguistic theory: The Rosendal papers. Amsterdam: John Benjamins, pp. 79-113.

Bocci, Giuliano (2008). «On the Syntax-Prosody Interface: an analysis of the prosodic properties of postfocal material in Italian and its implications». Nanzan Linguistics, Special Issue 5: 13-42.

Bocci, Giuliano (2009). On Syntax and Prosody in Italian. University of Siena, doctoral dissertation.

Bocci, Giuliano; Avesani, Cinzia (2006). «Focus Contrastivo nella periferia sinistra della frase: un solo accento, ma non solo un accento». In: Savy, Renata; Crocco, Claudia (eds.). Analisi prosodica. Teorie, modelli e sistemi di annotazione. Atti del II convegno nazionale AISV Associazione Italiana di Scienze della Voce, Salerno, 30.X-2.XII.2005. Rimini: EDK.

Bocci, Giuliano; Avesani, Cinzia (2008). «Deaccent given or define focus? Where Italian doesn't sound like English». Paper presented at XXXIV «Incontro di Grammatica Generativa», 21-23 February 2008. University of Padua.

Brunetti, Lisa (2004). A Unification of Focus. Padova: Unipress.

Brunetti, Lisa (2009). «Discourse Functions of Fronted Foci in Italian and Spanish». In: Dufter, Andreas; Jacob, Daniel (eds.). Focus and Background in Romance Languages. Amsterdam: John Benjamins, pp. 43-81.

Cardinaletti, Anna (2009). «On a (wh-)moved Topic in Italian, compared to Germanic». In: Alexiadou, Artemis; Hankamer, Jorge; McFadden, Thomas; Nuger, Justin; Schäfer, Florian (eds.). Advances in Comparative Germanic Syntax. Amsterdam: John Benjamins, pp. 3-40.

Ciconte, Francesco Maria (2010). Existential constructions of Early Italo-Romance Vernaculars. University of Manchester, doctoral dissertation.

Cinque, Guglielmo (1986). «Bare quantifiers, quantified NPs and the notion of operator at S-structure». Rivista di Grammatica Generativa 11: 33-63.

Cinque, Guglielmo (1990). Types of A'-Dependencies. Cambridge, Mass.: MIT Press. Cruschina, Silvio (2006). «Informational focus in Sicilian and the left periphery». In: Frascarelli, Mara (ed.). Phases of Interpretation.Berlin: Mouton de Gruyter. pp. 363-385. 
Cruschina, Silvio (2008). Discourse-related features and the syntax of peripheral positions. A comparative study of Sicilian and other Romance languages. University of Cambridge, doctoral dissertation. A revised version will appear as Discourserelated features and functional projections. Oxford/New York: Oxford University Press.

Cruschina, Silvio (2010a). «Fronting as Focalisation in Sicilian». In: D’Alessandro, Roberta; Ledgeway, Adam; Roberts, Ian (eds.). Syntactic Variation. The Dialects of Italy. Cambridge: Cambridge University Press, pp. 247-260.

Cruschina, Silvio (2010b). «Syntactic Extraposition and Clitic Resumption in Italian». Lingua 120: 50-73.

Cruschina, Silvio; Remberger, Eva-Maria (2009). «Focus Fronting in Sardinian and Sicilian». In: Proceedings of the 'XXXV Incontro di Grammatica Generativa', Siena 26-28 February 2009. STiL-CISCL Working Papers 3: 118-130.

Cruschina, Silvio; Sitaridou, Ioanna (2010). «From Modern to Old Romance: The Interaction between Information Structure and Word Order». University of Oxford, University of Cambridge, unpublished manuscript.

De Cat, Cécile (2007). French Dislocation. Interpretation, Syntax, Acquisition. Oxford/ New York: Oxford University Press.

Donati, Caterina; Nespor, Marina (2003). «From focus to syntax». Lingua 113: 1119-1142.

Drubig, Hans Bernard (2007). «Phases and the typology of focus constructions». In: Winkler, Susanne; Schwabe, Kerstin (eds.). On Information Structure, Meaning and Form. Amsterdam: John Benjamins, pp. 33-66.

É. Kiss, Katalin (1998). «Identificational focus versus information focus». Language 74: 245-273.

Fischer, Susann (2008). «Grammaticalisation within the IP-domain». In: Detges, Ulrich; Waltereit, Richard (eds.). The Paradox of Grammatical Change: Perspectives from Romance. Amsterdam: John Benjamins, pp. 107-126.

Fischer, Susann (2010). Word-Order Change as a Source of Grammaticalisation. Amsterdam: John Benjamins.

Fontana, Josep M. (1993). «Phrase structure and the syntax of clitics in the history of Spanish». University of Pennsylvania, Philadelphia, doctoral dissertation.

Fontana, Josep M. (1997). «On the integration of second position phenomena». In: van Kemenade, Ans; Vincent, Nigel (eds.). Parameters of morphosyntactic change. Cambridge: Cambridge University Press, pp. 207-249.

Frascarelli, Mara (2000). The Syntax-Phonology Interface in Focus and Topic Constructions in Italian. Dordrecht: Kluwer.

Frascarelli, Mara (2005). «Focus as predicate and Spell-Out conditions. Deriving crosslinguistic strategies from a unified account». University of Roma Tre, unpublished manuscript.

Frascarelli, Mara; Hinterhölzl, Roland (2007). «Types of Topics in German and Italian». In: Winkler, Susanne; Schwabe, Kerstin (eds.). On Information Structure, Meaning and Form. Amsterdam: John Benjamins, pp. 87-116.

Frascarelli, Mara; Puglielli, Annarita (2008). «Focus in the Force-Fin System. Information Structure in Cushitic Languages». In: Aboh, Enoch; Hartmann, Katharina; Zimmermann, Malte (eds.). Focus Strategies: Evidence from African languages. Berlin: Mouton de Gruyter, pp. 161-184. 
Horvath, Julia (1986). Focus in the Theory of Grammar and the Structure of Hungarian. Dordrecht: Foris.

Jones, Michael Allan (1988). «Sardinian». In: Harris, Martin; Vincent, Nigel (eds.). The Romance Languages. London: Routledge, pp. 314-350.

Jones, Michael Allan (1993). Sardinian Syntax. London: Rutledge.

Kaiser, Georg (1999). «A ordem das palavras e a posição do verbo finito no português antigo.» In: Actas do Congresso Internacional por motivo dos vinte anos do português no ensino superior. Budapest: Departamento de língua e literatura portuguesas da Faculdade de Letras da Universidade Eötvös Loránd de Budapeste, pp. 248-261.

Kaiser, Georg (2002). Verbstellung und Verbstellungswandel in den romanischen Sprachen. Tübingen: Niemeyer.

Lambrecht, Knud (1994). Information Structure and Sentence Form: Topic, Focus, and the Mental Representation of Discourse Referents. Cambridge: Cambridge University Press.

Ledgeway, Adam (2007). «Old Neapolitan word order: Some initial observations». In: Lepschy, Anna Laura; Tosi, Arturo (eds.). The languages of Italy: Histories and Dictionaries . Ravenna: Longo, pp. 121-149.

Ledgeway, Adam (2008). «Satisfying V2 in early Romance: Merge vs Move». Journal of Linguistics 44: 437-470.

Ledgeway, Adam (2011). «Syntactic and morphosyntactic typology and change in Latin and Romance». In: Maiden, Martin; Smith, John Charles; Ledgeway, Adam (eds.). The Cambridge History of the Romance Languages. Cambridge: Cambridge University Press.

Leonetti, Manuel; Escandell Vidal, M. Victoria (2009). «Fronting and Verum-Focus in Romance». In: Dufter, Andreas; Jacob, Daniel (eds.). Focus and Background in Romance Languages. Amsterdam: John Benjamins, pp. 155-204.

Lepori, Antonio (2001). Gramàtiga sarda po is campidanesus: duas obras in d-unu libru. Compendio di grammatica campidanese per italofoni. Quartu Sant'Elena: Edizioni C.R.

Lombardi, Alessandra (2007). «Posizione dei clitici e ordine dei costituenti nella lingua sarda medievale». In: Bentley, Delia; Ledgeway, Adam (eds.). Sui dialetti italoromanzi: saggi in onore di Nigel B. Vincent [The Italianist 27, Special supplement ]. Norfolk: Biddles, pp 133-147.

López, Luis (2009). A Derivational Syntax for Information Structure. Oxford/New York: Oxford University Press.

Martins, Ana Maria (2001). «The loss of IP-Scambling in Portuguese: Clause structure, word order variation and change». In: Lightfoot, David (ed.). Syntactic Effects of Morphological Change. Oxford: Oxford University Press.

Mensching, Guido; Remberger, Eva-Maria (2010). «The left periphery in Sardinian». In: D’Alessandro, Roberta; Ledgeway, Adam; Roberts, Ian (eds.). Syntactic Variation. The Dialects of Italy. Cambridge: Cambridge University Press, pp. 261-276.

Molnár, Valeria (2002). «Contrast in a contrastive perspective». In: Hasselgård, Hilde; Johansson, Stig K.A.; Behrens, Bergljot; Fabricius-Hansen, Cathrine (eds.). Information Structure in a Cross-linguistic Perspective. Amsterdam/New York: Rodopi, 147-161. 
Motapanyane, Virginia (1998). «Focus, checking theory and fronting strategies in Romanian». Studia Linguistica 55 (3): 227-243.

Munaro, Nicola (1999). Sintagmi interrogativi nei dialetti italiani settentrionali. Padua: Unipress.

Nespor, Marina; Guasti Maria Teresa (2002). «Focus to stress alignment and its consequences for acquisition». Lingue e Linguaggio 1: 79-106.

Paoli, Sandra (2003). COMP and the Left-Periphery: Comparative Evidence from Romance. University of Manchester, doctoral dissertation.

Parry, Mair (2010). «Non-canonical subjects in the early Italian vernaculars». Archivio Glottologico Italiano XCV, II: 190-226.

Pittau, Massimo (1991). Grammatica della lingua sarda. Varietà logudorese. Sassari: Carlo Delfino.

Poletto, Cecilia (2000). The higher functional field. Oxford/New York: Oxford University Press.

Poletto, Cecilia (2006). «Parallel Phases: a study on the high and low left periphery of Old Italian». In: Frascarelli, Mara (ed.). Phases of Interpretation. Berlin: Mouton de Gruyter, pp. 261-295.

Quer, Josep (2002). «Edging Quantifiers: On QP-Fronting in Western Romance». In: Beyssade, Claire; Bok-Bennema, Reineke; Drijkoningen, Frank; Monachesi, Paola (eds.). Romance Languages and Linguistic Theory 2000. Amsterdam: John Benjamins, pp. 253-270.

Remberger, Eva-Maria (2010). «Left peripheral interactions in Sardinian». In: Grohmann, Kleanthes K.; Tsimpli, Ianthi-Maria (eds.). Exploring the Left Periphery. Special issues of Lingua 120: 555-581.

Ribeiro, Ilza (1995). «Evidence for a verb-second phase in Old Portuguese». In: Battye, Adrian; Roberts, Ian (eds.). Clause Structure and Language Change. Oxford/New York: Oxford University Press, pp. 110-139.

Rizzi, Luigi (1996). «Residual verb second and the Wh-Criterion». In: Adriana Belletti and Luigi Rizzi (eds.) Parameters and Functional Heads. Oxford/New York: Oxford University Press, pp. 63-90. Originally published as Rizzi, Luigi (1991). «Residual verb second and the Wh-Criterion». Technical Reports in Formal and Computational Linguistics 2: 1-28. University of Geneva.

Rizzi, Luigi (1997). «The fine structure of the left periphery». In: Haegeman, Liliane (ed.). Elements of Grammar: Handbook in Generative Syntax. Dordrecht: Kluwer, pp. 281-337.

Rizzi, Luigi (2001). «On the position 'Int(errogative)' in the left periphery of the clause». In: Cinque, Guglielmo; Salvi, Giampaolo (ed.s). Current Studies in Italian Syntax. Essays offered to Lorenzo Renzi. Amsterdam: Elsevier, 287-296.

Rizzi, Luigi (2006). «On the Form of Chains: Criterial Positions and ECP Effects». In: Cheng, Lisa Lai-Shen; Corver, Norbert (eds.). Wh-Movement. Moving On. Cambridge, Mass.: MIT Press, pp. 97-133.

Roberts, Ian (1993). Verbs and Diachronic Syntax. A Comparative History of English and French. Dordrecht: Kluwer.

Roberts, Ian (2007). Diachronic Syntax. Oxford/New York: Oxford University Press.

Roberts, Ian; Roussou, Anna (2003). Syntactic Change: A Minimalist Approach to Grammaticalization. Cambridge: Cambridge University Press. 
Rooth, Mats (1992). «A theory of Focus Interpretation». Natural Language Semantics 1: 75-116.

Salvi, Giampaolo (2000). «La formazione del sistema V2 delle lingue romanze antiche». Lingua e Stile 35: 665-692.

Salvi, Giampaolo (2001). «The two sentence structures of early Romance». In: Cinque, Guglielmo; Salvi, Giampaolo (eds.). Current Studies in Italian Syntax. Essays offered to Lorenzo Renzi. Amsterdam: Elsevier, pp. 297-312.

Salvi, Giampaolo (2004). La formazione della strutture di frase romanza. Ordine delle parole e clitici dal latino alle lingue romanze antiche. Tübingen: Niemeyer.

Salvi, Giampaolo (2011). «Morphosyntactic Persistence from Latin into Romance». In: Maiden, Martin; Smith, John Charles; Ledgeway, Adam (eds.). The Cambridge History of the Romance Languages. Cambridge: Cambridge University Press.

Selkirk, Elisabeth (2002). „Contrastive FOCUS vs. presentational focus: Prosodic evidence from right node raising in English». In: Bel, Bernard; Marlien, Isabelle (eds.). Speech Prosody 2002: Proceedings of the 1st International Conference on Speech Prosody. Aix-en-Provence: Laboratoire Parole et Langage, pp. 643-646.

Sigurðsson, Halldór Á. (2004). «The syntax of Person, Tense, and speech features». Italian Journal of Linguistics 16: 219-251.

Sitaridou, Ioanna (2006). «A comparative study of word order in Old Romance». University of Cambridge, unpublished manuscript. To appear in: Carlier, Anne; Lamiroy, Béatrice; De Mulder, Walter (eds.). Folia Linguistica, Special Issue on «The pace of Grammaticalization in Romance».

Torres Morais, Maria Aparecida (1995). Do Português Clássico ao Português Moderno: um estudo da cliticização e do movimento do verbo. Campinas: Unicamp, doctoral dissertation.

Vallduví, Enric; Vilkuna, Maria (1998). «On rheme and contrast». In: Culicover, Peter W.; McNally, Louise (eds.). Syntax and Semantics 29: The Limits of Syntax. San Diego: Academic Press, pp. 79-108.

van Leusen, Noor (2004. «Incompatibility in context: A diagnosis of correction». Journal of Semantics 21 (4): 415-442.

Vance, Barbara (1997). Syntactic Change in Old French: Verb-Second and NullSubjects. Dordrecht: Kluwer.

Vanelli, Laura (1986). «Strutture tematiche in italiano antico». In: Stammerjohann, Harro (ed.). Tema-Rema in Italiano. Tübigen: Gunter Narr Verlag, pp. 249-273.

Vanelli, Laura (1999). «Ordine delle parole e articolazione pragmatica dell'italiano antico: la 'prominenza' pragmatica della prima posizione nella frase». Medioevo Romanzo 23 (2): 229-246.

Vilkuna, Maria (1995). «Discourse configurationality in Finnish». In: É. Kiss, Katalin (ed.). Discourse-Configurational Languages. Oxford/New York: Oxford University Press, pp. 244-268.

Zagona, Karen (2002). The Syntax of Spanish. Cambridge: Cambridge University Press. Zubizarreta, Maria Luisa (1998). Prosody, Focus and Word Order. Cambridge, Mass.: MIT Press.

Zubizarreta, Maria Luisa (1999). «Las funciones informativas: tema y foco». In: Bosque, Ignacio; Demonte, Violeta (eds.). Gramática Descriptiva de la Lengua Española. Madrid, Real Academia Española: Espasa, pp. 4215- 4244. 